\title{
MENINGKATKAN KEMAMPUAN BERCERITA SISWA KELAS III SDN 1 MANGARAN, KEC. MANGARAN DENGAN MENGGUNAKAN PERMAINAN KREATIF BERBASIS KEBUDAYAAN LOKAL
}

\author{
Aenor Rofek ${ }^{1)}$ \\ 1) Universitas Abdurachman Saleh Situbondo \\ gonzalesrofik99@gmail.com
}

\begin{abstract}
ABSTRAK: Keterampilan berbicara adalah keterampilan untuk mengungkapkan gagasan, pikiran, dan perasaan secara lisan. Berbicara adalah bentuk komunikasi yang membentuk perilaku manusia yang memanfaatkan faktor fisik, yaitu alat ucap, berupa suara, gerakan tubuh, mimik untuk mempertegas isi pembicaraan. Berdasarkan observasi awal di SDN 1 Mangaran, Kec. Mangaran. Kab.Situbondo terdapat 30 siswa di kelas III, para siswa sebagian besar merasa takut dalam bercerita. Pada kegiatan pembelajaran bercerita hanya 9 siswa yang berani bercerita dengan lancar, sedangkan siswa yang lain masih kurang kemampuan berceritanya. Hasil peningkatan pembelajaran yang dilakukan dalam rangka peningkatan kemampuan berbicara siswa kelas 3 SDN 1 Mangaran sudah dikatakan sudah berhasil.
\end{abstract}

Kata kunci: Penelitian tindakan kelas, kemampuan berbicara, dan permainan tradisional berbasis budaya lokal.

ABSTRACT: Speaking skills are skills to express ideas, thoughts, and feelings verbally. Speaking is a form of communication that shapes human behavior that utilizes physical factors, namely utterances, in the form of sounds, body movements, expressions to reinforce the contents of the conversation. Based on preliminary observations at SDN 1 Mangaran, Kec. Mangaran Situbondo District, there are 30 students in class III, most students feel afraid in telling stories. In storytelling learning activities only 9 students who dare to tell stories fluently, while other students still lack the ability to tell stories. The results of increased learning done in order to improve the speaking skills of students in grade 3 at SDN 1 Mangaran have been said to have been successful.

Keywords: Classroom action research, speaking skills, and traditional culture-based local games..

\section{PENDAHULUAN}

Pembelajaran bahasa Indonesia terbagi dalam empat keterampilan berbahasa yaitu keterampilan mendengarkan (menyimak), berbicara, membaca dan menulis. Keterampilan berbicara adalah keterampilan untuk mengungkapkan gagasan, pikiran, dan perasaan secara lisan. Berbicara adalah bentuk komunikasi yang membentuk perilaku manusia yang memanfaatkan faktor fisik, yaitu alat ucap, berupa suara, gerakan tubuh, mimik untuk mempertegas isi pembicaraan. Berdasarkan observasi awal di SDN 1 Mangaran, Kec. Mangaran. Kab.Situbondo terdapat 30 siswa di kelas III, para siswa sebagian besar merasa takut dalam bercerita. Pada kegiatan pembelajaran bercerita hanya 9 siswa yang berani bercerita dengan lancar, sedangkan siswa yang lain masih kurang kemampuan berceritanya. Ada siswa yang hanya bercerita satu kalimat atau tiga kalimat, dan ada juga siswa yang diam ketika disuruh bercerita.

Sumber belajar adalah modal utama siswa untuk belajar. Sumber belajar yang kurang memadai atau terbatas menyebabkan terhambatnya proses belajar mengajar. Di SDN 1 Mangaran, Kec. Mangaran. sumber belajar yang tersedia terutama buku cerita masih kurang. Buku-buku cerita yang ada hanya sedikit dan buku yang ada sudah terbitan 
lama. Di kelas-kelas terutama kelas III media yang mendukung di dalam kelas juga masih sedikit. Di kelas hanya ada gambar para pahlawan, sedangkan mading-mading sebagai hasil karya siswa sebagai ajang kreativitasnya tidak ada.

Kegiatan pembelajaran guru di kelas III SDN 1 Mangaran, Kec. Mangaran. Metode yang digunakan hanya menggunakan metode ceramah, tanpa ada variasi metode yang lain. Meskipun sekarang sudah kurikulum K13, akan tetapi para guru lebih menyukai metode lama. Guru menerangkan siswa mendengarkan, tanpa ada respon dari siswa untuk mengembangkan bakat dan kreativitasnya.

Permasalahan yang terakhir adalah hubungan antara siswa dengan siswa dan guru dengan siswa kurang terjalin. Siswa di kelas III SDN 1 Mangaran, Kec. Mangaran dalam berinteraksi dengan teman-temannya kurang adanya sosialisasi. Siswa lebih menyukai berteman dengan teman sebangkunya saja atau biasanya membentuk kelompok sendiri. Masalah hubungan siswa dengan guru ini sungguh memprihatinkan. Guru adalah pemimpin dan berkuasa di kelas dan siswa harus tunduk pada perintah guru. Ketika guru menerangkan, siswa harus diam mendengarkan dan ada rasa ketakutan siswa kepada guru. Ketakutan siswa tampak ketika siswa disuruh bertanya atau diberi pertanyaan diam saja dan hanya beberapa murid saja yang mempunyai keberaniaan bertanya atau menjawab.

Tiga permasalahan di atas perlu pembenahan yang betul untuk membawa siswa belajar lebih baik, menyenangkan, dan meningkatkan kreatifitas siswa. Ada sebuah metode yang menarik yang diharapkan bisa mengatasi ketiga masalah di atas. Metode yang menarik itu adalah metode permainan kreatif. Arif dan Napitupulu (dalam Yeni;2003:11) mengatakan bahwa permainan memberi kesempatan yang menyenangkan untuk belajar yang hampir tidak disadari dan alat yang efektif untuk merangsang minat warga belajar yang berperan serta. Permainan kreatif adalah pengajaran dengan permainan yang tidak membosankan dan menjenuhkan, karena adanya variasi-variasi dalam permainan.

Pembelajaran bercerita di SDN 1 Mangaran, Kec. Mangaran yang kurang menyenangkan bagi siswa, karena rasa ketakutan perlu adanya cara yang tepat. Apabila guru mengajar dengan menggunakan permainan kreatif, akan berpengaruh pada kemampuan siswa dan hasil belajar yang akan dicapai dalam proses pembelajaran akan meningkat. Oleh karena itu, penelitian ini berjudul "Meningkatkan Kemampuan Bercerita Siswa Kelas III SDN 1 Mangaran, Kec. Mangaran dengan Menggunakan Permainan Kreatif berbasis kebudayaan lokal"

\section{METODE PENELITIAN}

\section{Rancangan Penelitian dan Jenis Penelitian}

Penelitian Tindakan Kelas (PTK) bertujuan untuk memecahkan masalah yang terdapat dalam pembelajaran kemampuan bercerita siswa di kelas kelas III SDN 1 Mangaran. Langkah-langkah dalam penelitian ini adalah sebagai berikut:

\section{Pra Siklus}

Pada tahap ini peneliti mengadakan pengamatan awal untuk mengetahui aktivitas dan kemampuan siswa dalam mengikuti pelajaran Bahasa Indonesia. 


\section{Siklus 1}

a) Perencanaan

Tahap perencanaan yang dilakukan peneliti meliputi kegiatan penyusunan rencana tindakan yang akan dilaksanakan berdasarkan masalah yang ditemukan di lapangan.

b) Tindakan

Pelaksanaan tindakan pada siklus I ini, guru melaksanakan pembelajaran bercerita berdasarkan silabus dan skenario yang telah disusun.

1) Pendahuluan

a) Guru mengajak siswa untuk berkumpul membentuk lingkaran

b) Guru sebagai model bercerita kepada siswa

c) Guru menjelaskan indikator yang ingin dicapai dalam pembelajaran.

d) Guru menjelaskan unsur-unsur pokok dalam bercerita.

2) Kegitan inti

a) Guru menyuruh satu anak yang mau duduk di tengah-tengah lingkaran.

b) Guru menyuruh anak yang ditengah lingkaran memutar botol yang di dalam botol berisi kertas yang di lipat dengan tema cerita.

c) Guru menyuruh anak untuk bercerita sesuai dengan tema yang dialami.

d) Lanjutkan terus sampai selesai.

3) Penutup

Guru dan siswa bersama-sama melakukan refleksi terhadap pembelajaran yang telah dilakukan berupa manfaat apa yang didapat siswa dalam pembelajaran.

c) Observasi

Pada tahap ini, peneliti melakukan pengamatan dan mencatat untuk megetahui aktivitas pembelajaran.

d) Refleksi

Langkah terakhir adalah tahap refleksi. Refleksi dilakukan dengan cara mengolah data, menganalisis, menjelaskan, dan menyimpulkan bagaimanakah tingkat perubahan aktivitas siswa dalam pembelajaran serta berapa besar peningkatan prestasi belajar siswa.

\section{Siklus II}

Siklus II merupakan tindakan perbaikan (remedial). Pada siklus ini diterapkan untuk mengatasi kekurangan dan kelemahan pada siklus I, sehingga pada siklus II diharapkan diperoleh hasil yang lebih baik daripada siklus I.

\section{HASIL DAN PEMBAHASAN}

\section{Kemampuan Bercerita Siswa}

Pelaksanaan penilaian kemampuna bercerita dilakukan pada saat siswa bercerita. Berikut ini dipaparkan hasil kemampuan bercerita siswa kelas III SDN I Mangaran Kec. 
Mangaran Kab. Situbondo pada saat diterapkan pembelajaran permainan kreatif berbasis budaya lokal.

Tabel 1. Kemampuan Bercerita Prasiklus

\begin{tabular}{|c|c|c|c|c|c|c|c|c|}
\hline \multicolumn{9}{|c|}{ Kemampuan Bercerita } \\
\hline No & Nama Siswa & I & II & III & IV & $\mathbf{V}$ & Jumlah & Kriteria \\
\hline 1 & $\begin{array}{l}\text { Ahmad Sa'id Agil } \\
\text { Febriyandika }\end{array}$ & 3 & 2 & 3 & 2 & 2 & 12 & Kurang \\
\hline 2 & Alief Yuda Hamdhani & 2 & 2 & 2 & 2 & 3 & 11 & Kurang \\
\hline 3 & Alifatur Rofifah & 2 & 2 & 2 & 2 & 2 & 10 & Kurang \\
\hline 4 & Andika Putra Prasetyo & 3 & 2 & 1 & 2 & 2 & 10 & Kurang \\
\hline 5 & Azka Zhafirah & 1 & 1 & 1 & 2 & 1 & 6 & $\begin{array}{c}\text { Sangat kurang } \\
\text { baik }\end{array}$ \\
\hline 6 & Cahya Lailatul Qodaria & 2 & 3 & 3 & 2 & 2 & 12 & Kurang \\
\hline 7 & Citra Dwi Ariyanti & 2 & 1 & 2 & 2 & 1 & 8 & $\begin{array}{c}\text { Sangat kurang } \\
\text { baik }\end{array}$ \\
\hline 8 & Dani Firmansyah Sinaga & 1 & 2 & 3 & 3 & 2 & 11 & Kurang \\
\hline 9 & Dila Shintia & 1 & 1 & 1 & 1 & 2 & 6 & $\begin{array}{c}\text { Sangat kurang } \\
\text { baik }\end{array}$ \\
\hline 10 & Faiqotus Sholeha & 1 & 2 & 2 & 2 & 2 & 7 & $\begin{array}{c}\text { Sangat kurang } \\
\text { baik }\end{array}$ \\
\hline 11 & Fanisa Shiva Unay Zahroya & 3 & 2 & 2 & 1 & 5 & 9 & Kurang \\
\hline 12 & Farhan Ramadhani & 4 & 3 & 1 & 2 & 2 & 12 & Kurang \\
\hline 13 & Fitria Ainiatul Hasanah & 3 & 2 & 2 & 2 & 2 & 11 & Kurang \\
\hline 14 & Ilhamidatus Sholeha & 2 & 3 & 2 & 1 & 1 & 9 & Kurang \\
\hline 15 & Moh Syahrul Nizam & 3 & 1 & 1 & 2 & 2 & 9 & Kurang \\
\hline 16 & Moh. Ainul Arifin & 3 & 3 & 2 & 2 & 2 & 15 & Cukup \\
\hline 17 & Moh. Iqbal Ramadhani & 2 & 1 & 4 & 2 & 4 & 13 & Kurang \\
\hline 18 & Moh. Raihan Zamir & 2 & 3 & 2 & 2 & 3 & 13 & Kurang \\
\hline 19 & $\begin{array}{l}\text { Much. Rohmil Gabriel } \\
\text { Azizky }\end{array}$ & 3 & 4 & 3 & 3 & 2 & 15 & Cukup \\
\hline 20 & Muhammad Ali & 3 & 3 & 3 & 4 & 3 & 16 & Cukup \\
\hline 21 & Muhammad Ibrohim Adzib & 2 & 2 & 2 & 2 & 3 & 11 & Kurang \\
\hline 22 & $\begin{array}{l}\text { Muhammad Sultan Arifin } \\
\text { Hakim }\end{array}$ & 2 & 3 & 1 & 2 & 2 & 10 & Kurang \\
\hline 23 & Natasha Vika Asshuffa & 2 & 2 & 1 & 2 & 1 & 8 & $\begin{array}{c}\text { Sangat kurang } \\
\text { baik }\end{array}$ \\
\hline 24 & Nias Alkhansa & 2 & 2 & 2 & 2 & 2 & 11 & Kurang \\
\hline 25 & Octaviana Ariyanti & 2 & 1 & 1 & 3 & 2 & 9 & Kurang \\
\hline 26 & Putri Aulia & 2 & 3 & 2 & 1 & 2 & 10 & Kurang \\
\hline 27 & Shavira Amelia Faizzah & 2 & 2 & 1 & 1 & 1 & 7 & $\begin{array}{c}\text { Sangat kurang } \\
\text { baik }\end{array}$ \\
\hline 28 & Tegar Ainul Yaqin & 2 & 2 & 2 & 2 & 2 & 11 & Kurang \\
\hline 29 & Unzila Riskikah & 3 & 4 & 3 & 3 & 2 & 15 & Cukup \\
\hline 30 & Zainur Rusdi & 2 & 1 & 4 & 2 & 4 & 13 & Kurang \\
\hline
\end{tabular}

Keterangan : I : Ketepatan ucapan

II : Pilihan kata

III : Keberanian
IV : Kelancaran

$\mathrm{V}:$ Penguasaan topik

Tabel di atas menunjukkan bahwa dari 30 siswa, 6 siswa atau 22,22\% masuk pada tingkatan antara 5-8 dengan kriteria sangat kurang baik. Sedangkan 20 siswa atau 66,67\% dengan tingkatan skala 9-13 memiliki kemampuan bercerita kurang, 4 siswa atau 11,11\% masuk pada tingkatan antara 14-17 dengan kriteria cukup. Nilai rata-rata kelas yang 
dicapai yaitu 10,41 dengan kriteria kurang. Berdasarkan penilaian tersebut maka dapat diketahui bahwa rata-rata kelas belum mencapai kriteria keberhasilan.

Perolehan nilai keterampilan bercerita juga dapat dilihat dari setiap kriteria kemampuan bercerita. Berikut ini akan dijelaskan perolehan nilai setiap kriteria kemampuan bercerita.

1) Ketepatan Ucapan

Dari 30 siswa terdapat 4 siswa atau $14,8 \%$ pengucapan bahasa sangat kurang baik dan 16 siswa atau 51,9\% masih kurang. Sedangkan 9 siswa atau 29,6\% tergolong cukup dan 1 siswa atau 3,7\% tergolong baik.

2) Pilihan Kata

Pilihan kata yang digunakan siswa pada saat bercerita masih terbatas dan belum mampu mengembangkannya dengan luas. Tampak bahwa dari 30 siswa sebanyak 6 siswa atau 22\% sangat kurang baik, 14 siswa atau 44\% kategori kurang, 9 siswa atau $30 \%$ pilihan kata sudah cukup dan 1 siswa atau $4 \%$ sudah baik.

3) Keberanian

Tingkat keberanian siswa pada saat tampil di depan kelas masih kurang. Dari 30 siswa terdapat 9 siswa atau 33\% masih sangat kurang berani, 14 siswa atau 44\% kategori kurang, 6 siswa atau 19\% cukup dalam keberanian, dan 1 siswa atau 4\% keberanian siswa sudah baik.

4) Kelancaran

Dalam kelancaran diperoleh data dari 30 siswa diketahui sebanyak 6 siswa atau 18,5\% sangat kurang lancar, 19 siswa atau 66,7\% kurang lancar, 4 siswa atau 11,1\% cukup lancar, daan 1siswa atau 3,7\% kategori baik.

5) Penguasaan Topik

Penguasaan topik siswa dari 30 siswa sebanyak 5 siswa atau 18,5\% masih sangat kurang, 16 siswa atau 59,3\% kurang dalam penguasaan topik, 6 siswa atau 14,8\% sudah cukup, 1 siswa atau 3,7\% baik dan 2 atau 3,7\% sangat baik.

\section{Kemampuan Bercerita Siklus I}

Tindakan yang dilakukan peneliti pada saat berlangsungnya proses bercerita yaitu melakukan penilaian terhadap kemampuan bercerita siswa. Dari data hasil tes siklus 1 menunjukkan bahwa dari 30 siswa, 5 siswa atau 18,5\% masuk pada tingkatan antara 5-8 dengan kriteria kurang baik. Sedangkan 15 siswa atau 55,5\% dengan tingkatan skala 913 memiliki kemampuan bercerita kurang, 7 siswa atau 18,5\% masuk pada tingkatan antara14-17 dengan kriteria cukup, dan 3 siswa atau 7,5\% mencapai tingkatan skala 1821 dengan kriteria baik. Nilai rata-rata kelas yang dicapai yaitu 12,22 dengan kriteria kurang. Berdasarkan penilaian tersebut maka dapat diketahui bahwa nilai rata-rata kelas belum mencapai kriteria keberhasilan. Perolehan nilai keterampilan bercerita juga dapat dilihat dari per kriteria kemampuan bercerita. Berikut ini akan dijelaskan perolehan nilai per kriteria kemampuan bercerita siswa.

1) Ketepatan ucapan

Dari 30 siswa terdapat 2 siswa atau 7\% pengucapan bunyi bahasanya sangat kurang sesuai dan 10 siswa atau 37\% masih kurang sesuai karena pengucapan bunyi bahasa yang digunakan kurang tepat. Sedangkan 12 siswa atau 37\% siswa tergolong cukup, 6 siswa atau 19\% siswa tergolong baik. Meskipun logat berbicara terpengaruh dengan bahasa daerah akan tetapi hal tersebut dapat diterima dengan baik oleh pendengar 
2) Pilihan Kata

Pilihan kata yang digunakan siswa pada saat bercerita masih terbatas dan belum mampu mengembangkannya dengan luas. Hal tersebut tampak bahwa dari 30 siswa 2 siswa atau 7,41\% pilihan kata yang digunakan masih sangat kurang dan 12 siswa atau $44,44 \%$ pilihan kata yang digunakan masih kurang. Masih banyak siswa menggunakan kata tidak baku dan berbelit-belit dalam pembicaraannya. Kalimat yang digunakan belum tersusun dengan baik. Selain itu siswa masih belum dapat mengembangkan kosakata yang digunakan, sejumlah 13 siswa atau 40,74\% pilihan kata yang digunakan tergolong cukup dan sisanya 3 siswa atau 7,41\% tergolong baik.

\section{3) Keberanian}

Tingkat keberanian siswa pada saat tampil di depan kelas masih kurang. Dari 30 siswa terdapat 6 siswa atau 22\% masih kurang baik, baik dalam mengadakan kontak dengan pendengar sehingga saat siswa bercerita kurang mengarah kepada pendengar. Dari 30 siswa ada 10 siswa atau $37 \%$ tergolong kurang dalam hal keberanian. Hal ini dikarenakan siswa masih malu dalam bercerita dengan teman-temannya dan ada juga pada saat bercerita senyum-senyum dan tertawa. Penampilan siswa yang tegang serta sikap kaku dan sering menggerak-gerakkan tangan, membuat siswa mengalihkan perhatiaannya terhadap kegiatan bercerita. Keberanian yang cukup hanya dimiliki oleh 9 siswa atau 26\% dan 1 siswa atau $15 \%$ masuk pada kriteria baik. Siswa ini terlihat tenang pada saat bercerita dan suara cukup jelas menjangkau seluruh ruangan kelas.

4) Kelancaran

Dalam hal kelancaran berbahasa, siswa juga masih terlihat kurang terampil. Hal ini dapat dilihat pada perolehan nilai mereka. Dari 30 siswa ada 5 siswa atau 18,52\% masih tergolong sangat kurang dalam kelancaran berbahasa, 14 siswa atau 51,85\% tergolong kurang, 7 siswa atau 18,52\% tergolong cukup dan 4 siswa atau 11,1\% memliki kelancaran yang baik. Siswa terlihat gugup dan ragu-ragu sehingga mereka kurang lancar bercerita. Hal tersebut dapat terlihat dari pembicaraan mereka yang sering terputus-putus.

5) Penguasaan Topik

Penguasaan materi oleh siswa dipengaruhi oleh pemahaman mereka pada saat bercerita. Dari 30 siswa terdapat 4 siswa atau 15\%. sangat kurang menguasai topik, 11 siswa atau $41 \%$ tergolong kurang, dan 8 siswa atau $22 \%$ tergolong cukup, 1 siswa atau $7 \%$ menguasai topik dengan baik dan 4 siswa atau $15 \%$ sudah menguasai topik sangat baik. Kualitas isi pembicaraan siswa masih terbatas pada isi pertanyaan. Siswa memiliki kecenderungan meniru jawaban temannya dan isi cerita tidak sesuai dengan pertanyaan. atau tugas

Kekurangmampuan siswa menguasai materi disebabkan siswa belum melaksanakan tugas dari guru dengan baik. Berikut ini contoh penguasaan topik cerita siswa yang kurang sesuai dengan topik. Berdasarkan uraian tersebut, maka dapat dilihat bahwa kemampuan bercerita siswa dilihat dari rata-rata kelas maupun perkriteria kemampuan bercerita masih tergolong rendah. Untuk itu perlu adanya upaya agar kemampuan bercerita siswa lebih meningkat yaitu dengan menerapkan tindakan 
selanjutnya. Berdasarkan observasi terhadap kemampuan bercerita siswa, maka dilakukan refleksi unutk mengkaji kembali hasil tindakan. Hasil penilaian kemampuan bercerita pada siklus I menunjukkan bahwa kemampuan bercerita siswa yang diperoleh belum optimal. Nilai rata-rata kelas yang dicapai yaitu 12,37 dengan kriteria kurang.

Berdasarkan penilaian tersebut maka dapat diketahui bahwa nilai rata-rata kelas belum mencapai kriteria keberhasilan. Ketidak berhasilan tersebut dikarenakan siswa belum menguasai dengan baik faktor-faktor penunjang keefektifan bercerita. Siswa masih banyak mengulang kata yang tidak diperlukan dan gerakan tangan yang berlebihan, mengalihkan perhatian pendengar. Sikap yang tegang daan kaku mengakibatkan siswa kurang lancar dalam bercerita. Beberapa siswa juga terlihat masih belum menguasai topik pembicaraan. Dengan demikian perlu adanya perbaikan agar hal-hal seperti ini tidak terulang. Perbaikan akan dilaksanakan pada siklus II.

\section{Kemampuan Bercerita Siswa Siklus II}

Tindakan yang dilakukan peneliti setelah dilaksanakan pembelajaran dengan melalui permainan kreatif yaitu menganalisis hasil kemampuan bercerita siswa. Penilaian tersebut dapat dilihat pada tabel berikut.

Tabel 2. Kemampuan Bercerita Siklus II

\begin{tabular}{|c|c|c|c|c|c|c|c|c|}
\hline \multicolumn{9}{|c|}{ Kemampuan Bercerita } \\
\hline No & Nama Siswa & 1 & 11 & III & IV & $\mathbf{V}$ & Jumlah & Kriteria \\
\hline 1 & $\begin{array}{l}\text { Ahmad Sa'id Agil } \\
\text { Febriyandika }\end{array}$ & 3 & 3 & 3 & 4 & 4 & 17 & Cukup \\
\hline 2 & Alief Yuda Hamdhani & 3 & 4 & 3 & 3 & 4 & 17 & Cukup \\
\hline 3 & Alifatur Rofifah & 4 & 4 & 4 & 4 & 4 & 20 & Baik \\
\hline 4 & Andika Putra Prasetyo & 3 & 3 & 3 & 4 & 4 & 17 & Cukup \\
\hline 5 & Azka Zhafirah & 2 & 3 & 2 & 2 & 3 & 12 & Kurang \\
\hline 6 & Cahya Lailatul Qodaria & 3 & 3 & 3 & 3 & 4 & 16 & Cukup \\
\hline 7 & Citra Dwi Ariyanti & 4 & 4 & 4 & 3 & 3 & 18 & Baik \\
\hline 8 & $\begin{array}{l}\text { Dani Firmansyah } \\
\text { Sinaga }\end{array}$ & 4 & 4 & 3 & 3 & 3 & 17 & Cukup \\
\hline 9 & Dila Shintia & 3 & 3 & 4 & 4 & 3 & 17 & Cukup \\
\hline 10 & Faiqotus Sholeha & 4 & 3 & 4 & 4 & 3 & 18 & Baik \\
\hline 11 & $\begin{array}{l}\text { Fanisa Shiva Unay } \\
\text { Zahroya }\end{array}$ & 3 & 4 & 4 & 4 & 3 & 18 & Baik \\
\hline 12 & Farhan Ramadhani & 4 & 4 & 4 & 5 & 5 & 22 & Sangat baik \\
\hline 13 & Fitria Ainiatul Hasanah & 3 & 4 & 3 & 3 & 5 & 18 & Baik \\
\hline 14 & Ilhamidatus Sholeha & 4 & 3 & 3 & 2 & 4 & 16 & Cukup \\
\hline 15 & Moh Syahrul Nizam & 3 & 4 & 4 & 3 & 4 & 18 & Baik \\
\hline 16 & Moh. Ainul Arifin & 3 & 4 & 4 & 4 & 4 & 19 & Baik \\
\hline 17 & Moh. Iqbal Ramadhani & 2 & 3 & 4 & 4 & 4 & 17 & Cukup \\
\hline 18 & Moh. Raihan Zamir & 4 & 4 & 5 & 4 & 4 & 21 & Baik \\
\hline 19 & $\begin{array}{l}\text { Much. Rohmil Gabriel } \\
\text { Azizky }\end{array}$ & 4 & 3 & 3 & 4 & 4 & 18 & Baik \\
\hline 20 & Muhammad Ali & 4 & 5 & 5 & 5 & 4 & 23 & Sangat baik \\
\hline 21 & $\begin{array}{l}\text { Muhammad Ibrohim } \\
\text { Adzib }\end{array}$ & 3 & 3 & 3 & 2 & 3 & 14 & Cukup \\
\hline 22 & $\begin{array}{l}\text { Muhammad Sultan } \\
\text { Arifin Hakim }\end{array}$ & 3 & 4 & 4 & 4 & 4 & 19 & Baik \\
\hline 23 & Natasha Vika Asshuffa & 5 & 4 & 3 & 4 & 5 & 21 & Baik \\
\hline 24 & Nias Alkhansa & 4 & 4 & 4 & 4 & 5 & 21 & Baik \\
\hline 25 & Octaviana Ariyanti & 4 & 3 & 3 & 4 & 4 & 18 & Baik \\
\hline 26 & Putri Aulia & 3 & 3 & 4 & 4 & 4 & 18 & Baik \\
\hline 27 & Shavira Amelia Faizzah & 2 & 3 & 2 & 2 & 4 & 13 & Kurang \\
\hline
\end{tabular}




\begin{tabular}{|l|l|l|l|l|l|l|l|l|}
\hline 28 & Tegar Ainul Yaqin & 4 & 4 & 4 & 4 & 5 & 21 & Baik \\
\hline 29 & Unzila Riskikah & 3 & 4 & 4 & 4 & 4 & 19 & Baik \\
\hline 21 & Zainur Rusdi & 5 & 4 & 3 & 4 & 5 & & Baik \\
\hline
\end{tabular}

Keterangan :

\author{
I : Ketepatan ucapan \\ II : Pilihan kata \\ III : Keberanian
}

IV : Kelancaran

$\mathrm{V}:$ Penguasaan topik

Berdasarkan tabel di atas, dari 30 siswa yang masuk pada skala 10-13 sejumlah 2 siswa atau 7,4\% dengan kategori kurang, Siswa dengan tingkatan skala 14-17 sejumlah 9 siswa atau 33,3\% dengan kategori cukup, 15 siswa atau 51,9\% dengan kategori baik, dan 3 siswa atau 7,4\% dengan kategori sangat baik. Skor rata-rata kelas yang dicapai pada siklus kedua ini yaitu 17,88 dengan kategori cukup. Jadi pada siklus kedua ini, kemampuan bercerita siswa telah memenuhi kriteria keberhasilan. Selain pembahasan secara umum, berikut ini juga akan dipaparkan penilaian kemampuan bercerita siswa setiap kriteria.

1) Ketepatan Ucapan

Dari 30 siswa terdapat 3 siswa atau 11\% pengucapan bunyi bahasanya masih kurang jelas. Hal ini terjadi karena masih terdapat siswa mengulang kata-kata yang baru diucapkan. Namun pada siklus kedua ini, intensitas siswa yang sering mengulang kata-kata telah berkurang. Ada 12 siswa atau 44\% tergolong cukup, 13 siswa atau $41 \%$ tergolong baik, dan 2 siswa atau $4 \%$ tergolong sangat baik. Ketepatan ucapan siswa pada siklus II telah mengalami peningkatan.

2) Pilihan Kata

Pilihan kata yang digunakan siswa pada saat bercerita meningkat. Hal tersebut tampak dari 30 siswa terdapat 2 siswa atau 7,4\% kategori sangat kurang dan 12 siswa atau 22,22\% siswa pilihan kata yang digunakan masih kurang pada siklus I. Hal ini terjadi karena pada saat bercerita siswa masih menggunakan bahasa daerah. Akan tetapi, kesalahan dan kekurangan pada siklus I telah berkurang. Siswa berupaya tidak membuat kesalahan dengan cara menyusun kalimat sebaik-baiknya. Hal tersebut tampak bahwa dari 30 siswa, 13 siswa atau $48 \%$ pilihan kata yang digunakan tergolong cukup, sejumlah 15 siswa atau $48 \%$ tergolong baik, dan sejumlah 2 siswa atau $4 \%$ tergolong sangat baik.

3) Keberanian

Tingkat keberanian siswa pada saat tampil di depan kelas sudah cukup baik. Siswa mulai menunjukkan keberanian. Dari 30 siswa, 2 siswa atau 7,4\% masih kurang santai sehingga kelihatan tegang. Sedangkan 12 siswa atau 40,74\% siswa tergolong cukup, 13 siswa atau 44,44\% sudah baik, dan 3 siswa atau 7,41\% tergolong sangat baik. Mereka terlihat bersemangat dan pandangan sudah menyeluruh ke arah pendengar.

4) Kelancaran

Dari 30 siswa, terdapat 4 siswa atau 15\% masih kurang lancar bercerita. Hal ini terjadi karena dalam bercerita siswa masih tersendat-sendat dan tampak ragu-ragu. Siswa masih kurang percaya diri pada saat bercerita. Akan tetapi sejumlah 6 siswa atau 22\% tergolong cukup, 17 siswa atau 55\% memiliki kelancaran yang baik, dan 3 
siswa atau $7 \%$ tergolong sangat baik. Dalam hal ini siswa sudah mengalami peningkatan pada kelancaran bercerita.

5) Pengusaan Topik

Dari 30 siswa, terdapat 7 siswa atau 25,93\% tergolong cukup, 18 siswa atau 59,26\% tergolong baik dalam pengusaan topik, dan 5 siswa atau $14,81 \%$ sesuai topik cerita bahkan siswa telah mampu mencapai tingkatan yang paling baik. Hal tersebut diketahui dari reaksi positif dari siswa lain yang mendengarkan dengan seksama.

Dari hasil siklus II yang telah dilaksanakan, kemampuan bercerita siswa mengalami peningkatan sehingga dapat mencapai kriteria keberhasilan sesuai yang diharapkan oleh peneliti. Skor rata-rata kelas yang dicapai pada siklus kedua ini yaitu 17,88 dengan kriteria cukup, beberapa kekurangan pada siklus I telah diperbaiki di siklus II ini. Meskipun dalam beberapa aspek keefektifan bercerita, masih terdapat siswa yang mengulang kata, berbicara terputus-putus, akan tetapi penguasaan topik sudah mereka kuasai.

Berdasarkan hasil analisis penilaian kemampuan bercerita, diketahui bahwa telah terjadi peningkatan antara siklus I ke siklus II. Pada siklus II, kemampuan bercerita siswa telah mencapai kriteria keberhasilan sehingga tindakan tidak dilanjutkan. Maksudnya, pemberian tindakan sudah selesai. Sehingga dapat disimpulkan bahwa pembelajaran dengan menggunakan permainan kreatif dapat meningkatkan kemampuan bercerita siswa.

\section{Penerapan Pembelajaran Permainan Kreatif Berbasis Budaya Lokal.}

Berikut ini akan dijelaskan penerapan pembelajaran bercerita dengan menggunakan permainan kreatif, yang dapat digunakan sebagai rujukan untuk meningkatkan kemampuan bercerita. Pembelajaran ini dilakukan di kelas III SDN I Mangaran Kec. Mangaran Kab. Situbondo. Hasil penelitian dan pembahasan penerapan pembelajaran kreatif dipaparkan sebagai berikut.

a. Prasiklus

Pada tahap prasiklus, pembelajaran diikuti oleh seluruh siswa kelas III sebanyak 30 orang. Pada tahap ini, pembelajaran yang digunakan guru yaitu menggunakan metode ceramah. Pembelajaran dimulai dengan penjelasan guru mengenai pengertian bercerita. Guru memberikan penjelasan hal-hal apa yang harus diperhatikan dalam bercerita. Setelah guru memberikan penjelasan, guru menanyakan kepada siswa apakah sudah paham dengan apa yang telah dijelaskan oleh guru. Ternyata jawaban siswa menyatakan sudah jelas semua. Karena sudah jelas selanjutnya guru memanggil siswa menurut absen untuk ke depan bercerita. Siswa disuruh menceritakan pengalaman pribadi. Siswa menurut dan patuh perintah guru, tetapi terlihat dari wajah sikap siswa ketika ditunjuk ke depan. Ada siswa yang ke depan berjalan dengan tidak bersemangat, terdengar keluhan-keluhan lirih dari siswa, dan ada juga siswa yang duduk saja tidak berani maju ke depan dengan wajah takut dan pucat.

Pada saat kegiatan bercerita, hanya terlihat beberapa siswa saja yang dalam bercerita lancar dan bersemangat, sedangkan yang lainnya ada yang bercerita hanya sampai 2 dan 3 kalimat, dan ada yang hanya diam saja ketika berada di depan kelas. Terlihat dari observasi terlihat bahwa kemampuan bercerita mereka masih dalam kategori 
kurang.

Untuk mendukung kegiatan observasi, dilakukan wawancara pada guru dan siswa. Wawancara kepada siswa dilakukan untuk mengetahui tanggapan siswa terhadap pembelajaran yang telah berlangsung. Berdasarkan hasil wawancara terhadap siswa diketahui bahwa siswa takut bercerita karena merasa malu. Siswa takut bila bercerita melakukan kesalahan, tidak sesuai yang diinginkan guru. Akibatnya, banyak siswa yang tidak suka bercerita. Siswa dipancing dengan pertanyaan, kegiatan apa yang paling disuka, dan siswa serentak menjawab bermain.

Wawancara terhadap guru dilakukan untuk mengetahui kegiatan apa saja yang sudah dilakukan guru pada materi berbicara seperti :pidato dan membaca puisi. Kegiatan bercerita jarang digunakan karena siswa sulit untuk bercerita dan kegiatan membutuhkan waktu yang lama. Hasil pengamatan tersebut dapat menjelaskan bahwa kemampuan bercerita siswa masih tergolong rendah. Kondisi ini disebabkan oleh banyak faktor. Untuk itu perlu upaya agar kemampuan bercerita dapat ditingkatkan. Tindakan yang dilakukan yaitu dengan menerapkan permainan kreatif.

b. Siklus I

Kegiatan siklus I merupakan upaya perbaikan untuk meningkatkan kemampuan bercerita siswa dengan menggunakan permainan kreatif. Langkah-langkah yang ditempuh pada siklus I adalah sebagai berikut.

1) Perencanaan

Kegiatan yang dilakukan pada tahap ini, semua peralatan yang berkaitan dengan persiapan mengajar telah disiapkan, seperti penyusunan 1) perangkat pembelajaran yang meliputi rencana pembelajaran, silabus, dan sistem penilaian, 2) penyusunan skenario penerapan pembelajaran dengan menggunakan permainan kreatif, 3) menetapkan indikator ketercapaian dan menyusun instrumen pengumpul data yang terdiri dari lembar observasi terhadap guru dan siswa, lembar tes unjuk kerja siswa, daftar pertanyaan untuk wawancara terhadap guru dan siswa dan catatan lapangan.

2) Pelaksanaan

Pelaksanaan kegiatan belajar mengajar dilakukan sesuai dengan rencana pembelajaran dengan menggunakan permainan kreatif. Pembelajaran ini terbagi menjadi 3 tahap yaitu pendahuluan, kegiatan inti, dan penutup. Lebih jelasnya dapat diuraikan sebagai berikut.

a. Tahap Pendahuluan

Tindakan siklus I di laksanakan pada hari Sabtu 20 April 2019 di kelas III SDN I Mangaran Kec. Mangaran Kab. Situbondo. Siklus I dilaksanakan pada jam 3-4 atau pukul 08.00 sampai dengan pukul 09.00. Sebelum pelaksanaan pembelajaran dimulai, guru menjelaskan, secara singkat metode pembelajaran yang akan digunakakan. Tahap Kegiatan Inti

Pada tahap ini guru menyuruh salah satu anak untuk duduk di tengah-tengah lingkaran. Guru mengeluarkan botol yang berisi lipatan-lipatan kertas yang di dalamnya terdapat soal yang harus diselesaikan oleh siswa. Guru menyuruh siswa yang duduk di tengah lingkaran memutar botol. Pada saat botol berputar, maka botol itu akan berhenti sendirinya dan pada saat berhenti botol itu berhenti pada salah satu anak, 
kemudian anak disuruh mengambil salah satu lipatan kertas di dalam botol. kemudian siswa bercerita sesuai dengan isi pertanyaan di kertas yang mereka pilih. Setelah itu dilanjutkan siswa lainnya. Semua siswa disuruh oleh guru mengambil kertas di dalam botol satu persatu. Ternyata yang berperan memutar botol hanya dilakukan oleh guru, bukan siswa. Padahal skenario pembelajaran guru memberikan penjelasan teknikteknik penggunaannya, kemudian siswa sendiri yang memutar botol, giliran sesuai dengan dimana botol itu berhenti pada alah satu siswa. Sehingga proses pembelajaran kelihatan ramai, ada siswa yang langsung berani mengambil lotre yang berisi topik cerita, ada yang disuruh guru untuk mengambil. Ternyata ketika guru bertanya siapa yang belum mengambil undian, mereka menjawab sudah semua. Ternyata ada satu anak bilang kepada guru, kalau ada satu anak belum mengambil, tetapi diam saja.

Pada kegiatan bercerita, ada siswa yang bercerita lancar dan sesuai topik tetapi kebanyakan siswa kurang lancar bercerita dan penguasaan topik cerita yang tidak sesuai. Sikap siswa kelihatan tegang ketika bercerita, karena khawatir salah. Ketika ada siswa yang bercerita yang sesuai dengan keinginannya. Ada siswa yang menyela, bahwa ceritanya salah dan terjadilah keramaian. Tetapi guru bisa mengelola kelas, dengan memberi pengarahan, tidak apa-apa biar temannya bercerita sesuai dengan keinginannya sendiri.

b. Tahap Penutup

Pada kegiatan evaluasi siswa sudah terlihat ada perubahan yaitu siswa lebih mempunyai keberanian. Siswa lebih tenang dan santai ketika guru berbicara. Siswa ditanya apa yang dapat diambil dari pembelajaran ini. Walaupun begitu, siswa tetap diberi arahan guru. Tetapi siswa ketika diberi pertanyaan guru, mereka menjawab dengan serentak.

c. Hasil Observasi

Observasi yang dibahas di sini yaitu berupa aktivitas guru dilaksanakan pada saat pembelajaran sedang berlangsung. Observasi aktivitas guru dilakukan oleh beberapa rekan peneliti, sedangkan observasi aktivitas siswa dilakukan oleh peneliti. Observasi kepada guru sudah sesuai dalam menerapkan pembelajaran dengan menggunakan permainan kreatif. Berikut ini hasil observasi terhadap aktivitas guru pada saat pembelajaran.

\section{Siklus II}

Siklus II merupakan usaha perbaikan di siklus I. Usaha perbaikan ini meliputi halhal yang berkaitan dengan pelaksanaan tindakan yang belum sepenuhnya sempurna dilaksanakan pada siklus I. Siklus II ini dilakukan untuk lebih meningkatkan kemampuan bercerita siswa. Langkah-langkah dalam siklus II adalah sebagai berikut.

1) Perencanaan

Setelah mengadakan analisis hasil kegaitan pada siklus I, maka perlu dilakukan beberapa perbaikan agar hasil yang diharapkan dapat meningkat. Pada tahap ini semua persiapan yang dilakukan dan beberapa kelemahan yang terjadi pada siklus I telah disiapkan. Untuk itu perencanaan ulang yang berkaitan dengan persiapan mengajar perlu dilakukan. Persiapan yang dilakukan meliputi pengaturan waktu, mengatur tempat, mempersiapkan lembar penilaian, lembar observasi guru dan siswa, menyiapkan panduan wawancara, dan penjelasan kepada guru tentang skenario pembelajaran yang sesuai. 
2) Pelaksanaan

Tindakan siklus II dilaksanakan hari Sabtu pada tanggal 04 Mei 2019 pada jam pelajaran pertama yang dimulai pukul 08.00 sampai dengan pukul 09.00. Pada tahap ini, sebelum pembelajaran dimulai siswa diminta untuk mengatur ruang belajar. Pembelajaran ini terbagi menjadi tiga tahap yaitu pendahuluan, kegiatan inti, dan penutup.

a. Tahap Pendahuluan

Pada tahap ini, kegiatan belajar mengajar yang dilakukan dengan menggunakan permainan kreatif. Suasana kelas lebih tenang dari sebelumnya. Pembelajaran diawali dengan penjelasan ulang mengenai pembelajaran yang akan dilaksanakan. Penjelasan dilakukan agar siswa mengerti skenario pembelajarannya. Kemudian guru memberikan apersepsi dengan mengingatkan siswa terhadap pembelajaran yang telah lalu (siklus I). Dalam hal ini guru menanyakan informasi apa saja yang telah diperoleh dan manfaatnya bagi mereka. Selain itu guru menjelaskan hal-hal yang harus diperhatikan dalam bercerita, yaitu meliputi ketepatan ucapan, pilihan kata, keberanian, kelancaran, dan penguasaan topik.

b. Tahap Kegiatan Inti

Tahap-tahap yang harus dilakukan siswa pada kegiatan ini sama halnya dengan siklus pertama. Guru menjelaskan tentang teknik-teknik penggunaan permainan kreatif. Guru memberi kebebasan siswa untuk kerelaan yang pertama kali memutar botol. Ada beberapa siswa yang tunjuk tangan untuk menjadi yang pertama kali memutar botol. Guru memilih siswa yang pertama kali tunjuk tangan yang tercepat. Siswa yang telah terpilih untuk pertama memutar botol, duduk di tengah-tengah lingkaran anak-anak dan kemudian memutar botol. Botol berputar beberapa detik, dan berhenti. Pada saat berhenti pada ujung botol itu menunjuk pada satu anak, dan kemudian anak itu yang duduk di tengah lingkaran bergantian dengan siswa yang memutar botol, untuk mengambil kertas di dalam botol itu dan kemudian dia becerita sesuai dengan perintah pada tulisan. Siswa bercerita dengan kalimat sederhana dan jelas sesuai dengan topik. Sebelumnya guru sudah menjelaskan ketika bercerita jangan terlalu menggunakan kata-kata yang sulit dimengerti. Pergunakan kalimat yang sederhana. Siswa kebanyakan bercerita dengan lancar, karena mereka bercerita terserah dengan keinginannya. Siswa boleh bercerita dengan duduk atau berdiri sesuai dengan keinginan. Guru sebelumnya memberi peringatan kepada teman-temannya yang medengarkan tidak boleh mengejek, menggoda, dan menyela temanya ketika bercerita. Jadi proses bercerita siswa lancar dan sukses. Semua siswa bercerita tanpa dipaksa guru atau saling berebutan.

c. Tahap Penutup

Pada kegiatan evaluasi, siswa terlihat cukup aktif, kreatif dan berani dalam bercerita. Isi cerita mereka lebih kreatif dan bagus. Penggunaan bahasa mereka tidak monoton dan tidak meniru bahasa temannya. Mereka lebih berpikir kreatif sendiri. Sehingga hasilnya bercerita siswa memuaskan.

\section{KESIMPULAN}

Berdasarkan hasil penelitian Pada kegiatan Siklus 1 dari 30 siswa, 5 siswa atau 18,5\% masuk pada tingkatan antara 5-8 dengan kriteria kurang baik. Sedangkan 15 siswa atau 55,5\% dengan tingkatan skala 9-13 memiliki kemampuan bercerita kurang, 7 siswa atau 18,5\% masuk pada tingkatan antara14-17 dengan kriteria cukup, dan 3 siswa atau 
7,5\% mencapai tingkatan skala 18-21 dengan kriteria baik. Nilai rata-rata kelas yang dicapai yaitu 12,22 dengan kriteria kurang. Dan pada siklus II dari 30 siswa yang masuk pada skala 10-13 sejumlah 2 siswa atau 7,4\% dengan kategori kurang, Siswa dengan tingkatan skala 14-17 sejumlah 9 siswa atau 33,3\% dengan kategori cukup, 15 siswa atau 51,9\% dengan kategori baik, dan 3 siswa atau 7,4\% dengan kategori sangat baik. Skor rata-rata kelas yang dicapai pada siklus kedua ini yaitu 17,88 dengan kategori cukup. Jadi pada siklus kedua ini, kemampuan bercerita siswa telah memenuhi kriteria keberhasilan. Hasil peningkatan pembelajaran yang dilakukan dalam rangka peningkatan kemampuan berbicara siswa kelas 3 SDN 1 Mangaran sudah dikatakan sudah berhasil.

\section{DAFTAR RUJUKAN}

Arikunto, Suharsimi. 2002. ProsedurPenelitian : Suatu Pendekatan Praktek. Jakarta: Rineka Cipta.

Arsjad, Maidar dan Mukti U.S. 1991. Pembinaan Kemampuan Berbicara Bahasa Indonesia.

Jakarta : Erlangga.

Cremer dan Siregar. 1993. Permainan dan Latihan Dinamika Kelompok Proses Pengembangan Diri. Jakarta : Gramedia.

Hasibuan. J.J. Moedjiono. 1995. Proses Belajar Mengajar. Bandung : remaja Rosdakarya. Majid, Abdul Aziz. 2002. Mendidik dengan Cerita. Bandung : PT Remaja Rosdakarya.

Power, Brain. 2005. Permainan Kreatif Pengisi Waktu Luang. Jakarta : Erlangga.

Rofi' uddin, Ahmad. Rancangan Penelitian Tindakan. Lokakarya Tingkat lanjut Penelitian Kualiatif Angkatan VII Tahun 1998/1999 : Lembaga Penelitian IKIP Malang.

Somantri, T Sutjihati. 2006. Psikologi Anak Luar Biasa, PT Refika Aditama. Bandung.

Suhartiningsih. 2000. Kemampuan Bercerita Mahasiswa Calon Guru Sekolah Dasar : Pancaran Pendidikan : FKIP UNEJ.

Suhardjono. 2006. Penelitian Tindakan Kelas. Jakarta : Bumi Aksara. 
Volume 4, Nomor 1, Februari 2020 